\title{
Editorial
}

I was recently enjoying a cup of coffee in the food court of a large shopping centre and I noticed how some carers were relating the wheelchair users the were accompanying.

The carers were having lunch around a table whilst the service users in their chairs were lined up in front of an observation window overlooking a building site for a least twenty minutes. They appeared to be two separate groups with no eye contact, verbal and non-verbal communication. I thought what a serendipitous practice learning opportunity this would have been if a social work student had seen this and was able to use the experience to develop their practice.

It reminded me of just how many practice learning opportunities, planned or otherwise there can be. The General Social Care Council (the regulating body for social work in England) use the term 'Practice learning Opportunity' (PLO) to describe the periods of practice learning of up to 100 days that students must complete. In my opinion this does not highlight the breadth, depth and riches of the learning that takes place in what is universally known as a practice learning placement.

To help define the placement experience Doel et al, (2004), supported by NOPT,(2006) use the term 'Practice Learning Site' as:

The location/office/base from which the primary practice Learning opportunities are generated.

The term 'Placement' than can be used to describe the whole practice learning experience. The experience can be planned via learning agreements and contracts, but will of course also encompass many of the aforementioned spontaneous and serendipitous practice learning opportunities.

So, in conclusion let's hang on to that well used, familiar and understood term 'placement. Readers what do you think?

3 Journal of Practice Teaching \& Learning 7(1) 2006-07, pp.3-5. @ 2007 Whiting \& Birch Ltd 


\section{In this issue}

This edition represents a milestone in my editorship as it contains the first contribution from a current social work student, the first for many years. So, congratulations to Janine Buck who provides an account of her personal journey of learning whilst undertaking three very different types of placement. I am sure you will all be impressed with her thought provoking and very optimistic message regarding social work practice learning.

Carlton et al describe how they took the best of current practice and integrated this into an innovative and creative training course for those who are assessing the competence and learning of our future social workers. A major factor in the success of the course was the partnership they created between the local authority that provided care services and the university responsible for social work training.

Cooper and Hallam have added to the ongoing debate regarding 'reflection' and practice with their creative approach to teaching the subject to 'novice' social work students in Australia. They use both verbal and visual imagery as techniques to enhance a student's reflective abilities. Part of their rational for this is the multi-media imagery that our students are exposed to prior to commencing their training. Their model also emphasises the role reflection can play when encouraging learners to develop their problem solving and analytical abilities.

Douglas and Magee who work in the training and development units of Northern Ireland's Health and Social Services Boards describe how they have addressed the crucial issues of: Quality assurance, accreditation and professional development of practice teachers. An integrated system of support and training has been offered that is providing a pool of experienced and competent practice teachers. There has been a tendency in some parts of the United Kingdom for universities and local authorities to form consortia to enhance practice learning systems. The model appears eminently suitable for the development of such partnerships.

Hodgson and Walford provide a thought provoking paper that focuses on 'learning plans' for social work students who are undertaking their field work training. They identify the difficulties often encountered when using such plans and offer a practical and innovative model that places the learner firmly at the centre of the process.

4 Journal of Practice Teaching \& Learning 7(1) 2006-07, pp.3-5. @ 2007 Whiting \& Birch Ltd 


\section{Journal title}

Finally, you will have noticed a change in the appearance of the Journal, and from this volume, the title of the journal will change to Journal of Practice Teaching \& Learning in Social Work, Health \& Nursing. This title better reflects the actual nature and the wide range of the material which we publish.

\section{Steve Ambler*}

\section{References}

Doel, M., Deacon, L. and Sawdon, C. (2004) Audit of models of models of Practice Learning in the New Social Work Award. Sheffield: Sheffield Hallam University.

NOPT (2006) Good Practice Guide for Placements in the Social Work Degree.

* With thanks to Adrian Black, Journal Board Member, for his contribution to this editorial

\footnotetext{
5 Journal of Practice Teaching \& Learning 7(1) 2006-07, pp.3-5. ( 2007 Whiting \& Birch Ltd
} 